Please do not remove this page

RMIT

UNIVERSITY

\title{
Casting the Net Wider: Coping with an increasingly diverse international student body in Australia
}

Gomes, Catherine

https://researchrepository.rmit.edu.au/esploro/outputs/9921860788401341/filesAndLinks?institution=61RMIT_INST\&index=null

Gomes, C. (2017). Casting the Net Wider: Coping with an increasingly diverse international student body in Australia. In Quality Assurance in Asia-Pacific Universities: Implementing Massification in Higher Education (pp. 151-167). Palgrave Macmillan. https://doi.org/10.1007/978-3-319-46109-0

Document Version: Accepted Manuscript

Published Version: https://doi.org/10.1007/978-3-319-46109-0

Repository homepage: https://researchrepository.rmit.edu.au

(c) The Author(s) 2017

Downloaded On 2023/04/26 21:29:26 +1000

Please do not remove this page 
Thank you for downloading this document from the RMIT Research Repository.

The RMIT Research Repository is an open access database showcasing the research outputs of RMIT University researchers.

RMIT Research Repository: http://researchbank.rmit.edu.au/

\section{Citation:}

Gomes, C 2017, 'Casting the net wider: Coping with an increasingly diverse international student body in Australia' in Deane E. Neubaueur, Catherine Gomes (ed.) Quality Assurance in Asia-Pacific Universities: Implementing Massification in Higher Education, Palgrave Macmillan, Switzerland, pp. 151-167.

See this record in the RMIT Research Repository at:

https://researchbank.rmit.edu.au/view/rmit:42082

Version: Accepted Manuscript

Copyright Statement:

(c) The Author(s) 2017

Link to Published Version:

http://dx.doi.org/10.1007/978-3-319-46109-0 


\title{
Chapter 10
}

Casting the Net Wider: Coping with an increasingly an international student body in Australia

\author{
Catherine Gomes
}

\section{Introduction}

As an export industry, international education in Australia is a powerhouse, bringing in $\$ 19$ billion in full-fees and associated expenditures in 2015 alone while impacting on secondary industries such as rental accommodation, hospitality and tourism. The international education sector moreover currently employs more than 130,000 people. Recognizing the significance of international education, on 30 April 2016 Richard Colbeck, the Minister for International Education and Training, released a long-term roadmap known as the National Strategy for International Education 2025 to drive the sector for the ensuring decade. The strategy was first circulated as a draft a year earlier in April 2015 in order to gain feedback from international education stakeholders (Australian Government, 2015). The aim of the strategy, as Minister Colbeck notes, is to strengthen and solidify international education as " one of the five super growth sectors contributing to Australia"s transition from a resources-based to a modern services economy" and to "ensure Australia remains a leader in the provision of education services to overseas students" (Australian Government, v). In addition, the strategy points to the on-going benefits from this sector in terms of the bridges it builds between Australia and the rest of the world and particularly highlights the collaborative ventures Australia has with the rest of 
the world because of international education through research, trade, investment and social engagement. One of the most significant recommendations was to increase international student numbers from the current half a million to 990,000 by 2025 .

While the strategy generally acknowledges the significance of international education and international students to the economy and to the future of Australia"s engagement with Asia -- the region where the majority of current international students come from -- it does not acknowledge nor discuss the impact that increasing numbers of students have on institutions and on the wider community. Reflecting on these issues I provide some practical applications, which I have used in my large and diverse courses to show that the diversity of increasing numbers of international (and local) students provides an excellent opportunity for blending both international and local perspectives into the curriculum. I also point out though that while there are positive outcomes to gain within the curriculum, the real challenge of the increasing international student intake takes place outside the classroom. The increasing presence of international students has caused undue tensions in Australia with the media and the public typecasting them within unfair frameworks. Here I address these public and media concerns directly with evidence from my own ongoing research into the international student experience in Australia.

\section{National Strategy}

So what are the key elements of the Australian government"s national strategy on international education? Recognizing the potential to take the international education industry to the next level in order to make it one of the mainstays of the Australian economy, in what International Education Minister Colbert explains as “"'one of the five super growth sectors contributing to Australia"s transition from a resources-based to a modern services economy"," (Australian Government, 2016, p. 
v), the strategy recommends expanding international education beyond the Asian region. It advocates that the sector needs to look for emerging markets while still recruiting from the traditional sources of China, India and Southeast Asia. The reason why the strategy suggests recruiting from outside Asia is a fear that the market there has become saturated. Potential international students from Asia now have the option of not leaving the region but enrolling in other Asian nations for their qualifications. Emerging yet dynamic regional hubs of China, Taiwan, South Korea, Japan, Indonesia, Singapore and Malaysia are becoming attractive destinations for Asian and non-Asian students (e.g. from the Middle East) (UNESCO, 2016). These new education hubs are a direct threat to Australia"s billion dollar education industry and its secondary industries. In 2013 these regional hubs combined hosted 7 per cent of the global share of international students; edging out Australia which only had 6 per cent of the market share (UNESCO, 2016). Malaysia, for instance, has plans to increase its international student intake to 200,000 by 2020 (Hughes, 2015). Countries such as Malaysia and Singapore are also attractive because of the prospect of the availability of local jobs post-graduation. Potential new markets such as those in Latin America and the Middle East, which were highlighted in a previous draft of the national strategy (Australian Government, 2015, pp. 8 \& 26), are attractive targets because of the growing middle class in these regions. A strong middle class, as the previous draft of the strategy explained, would mean a growing number of families able to afford an overseas education for their children (Australian Government, 2015, pp. 8 \& 26). Recruiting from emerging markets is also a failsafe position to attract increasing numbers of young people to Australia looking to improve their educational qualifications. The recruiting of new students stems too from a fear of an oversaturation of the established markets in Asia since the strategy 
also reads international education as a two-way process in which Australia not only exports international education, but also sends its own students overseas in order to build bridges with host nations through schemes such as the New Colombo Plan (Department of Foreign Affairs and Trade, 2016).

In order to accomplish all this and thereby strengthening Australia"s position as an international education giant in this competitive yet lucrative industry, the strategy provides a multipronged strategy around three pillars. The first pillar known as "Strengthening the fundamentals", will be achieved by building on Australia"s current education, training and research system; providing students with the best education experience possible and keeping check on quality assurance and regulation. The second pillar "Making transformative partnerships" aims to strengthen (educational and research) partnerships both at home and abroad as well as with alumni in addition to enhancing local and international student, educator and researcher mobility. The final pillar sees Australia "Competing globally" by promoting the country a as a high-quality international education destination and by creating opportunities for further growth of the international education sector (e.g. in regional Australia) (Australian Government, 2016, p. 11).

In order to achieve these goals, the strategy, among other things, commits the federal government to work with state and territory governments, stakeholders, businesses and the wider community. So what are the positives that we can take out of the strategy?

\section{Value placed on industry and international students}

Asian-born international students after all, have had a presence in Australia ever since the commencement of the Colombo Plan in 1951 when soon-to-be decolonized nations and former colonies in the British Commonwealth sent 
sponsored students to be trained in skills that would assist in the economic, infrastructural and social development of these nations. By the 1980s, Australia had become a global player in the export of education by offering courses and qualifications that attracted students from Southeast Asia and, increasingly, from Northeast and South Asia. In 2016, education services brought in close to AUD\$19 billion through full-fee paying international students. ${ }^{1}$ By the end of 2015, 525,172 international students (including exchange students) were enrolled in educational institutions throughout Australia (Australian Department of Education and Training, 2015). Most of these students came from a range of different countries from Asia, the Middle East and elsewhere. However, the majority of international students came from Asia, with the top countries being China $(136,097)$, India $(53,568)$, Vietnam $(21,807)$, the Republic of Korea $(20,790)$ and Malaysia $(20,641)$ (Australian Department of Education and Training, 2016). While high school-going international students in Australia were also plentiful, their numbers have not been comparable to those who are undertaking post-secondary study in universities, vocational education and training (VET) institutes and English Language Intensive Courses for Overseas Students (ELICOS) colleges. International students today inhabit Australian cities and towns, supporting higher education institutions and high schools.

International students in higher education further contribute to the Australian economy through casual and seasonal employment. As a condition of their visas, international students are not allowed to hold full-time permanent jobs, since that would require a separate working visa. International students, however, are allowed to work a total of 40 hours per fortnight (Department of Immigration and Border Protection 2014). This means that they usually work part-time in contract or noncontract positions. International students often work in retail, hospitality, tourism, 
agriculture (e.g. fruit-picking), sales and telemarketing, administration or tutoring. Postgraduate international students, particularly doctoral candidates, often take on sessional tutoring jobs at universities (Australian Trade Commission, 2016). In 2009_ 2010 the median weekly income of students in employment was AUD\$564 (Australian Bureau Of Statistics, 2013). International students work primarily to support themselves since international student fees are high. The Australian government estimates that in 2014, an undergraduate degree cost between AUD $\$ 15,000$ and AUD $\$ 33,000$, a postgraduate Masters degree between AUD $\$ 20,000$ and AUD $\$ 37,000$, and a doctoral degree between AUD $\$ 14,000$ and AUD\$37,000 (Australian Trade Commission, 2016). Meanwhile, the estimated cost of living in a shared student apartment in the city of Melbourne was in 2016 AUD\$23,000 to AUD\$31,000 per annum (Student Services, The University of Melbourne 2016).

In the meantime, approximately one in five (22 percent) of all tertiary students were international students with New South Wales and Victoria supporting the largest number of students, with a combined share of 58 percent of the entire Australian market (Australian Bureau Of Statistics, 2011). Fifty-five per cent of the combined New South Wales and Victorian international student population live and study in Melbourne alone (City of Melbourne 2013). These international students attend the universities, VET institutes and ELICOS colleges within the city and occupy residential apartments in the heart of the central business district (CBD). The strategy is not wrong in its assumptions of the positive impact international students have on the Australian economy.

While the strategy is no doubt aspirational and driven by economic interests, it was heartening to read its acknowledgement of the value of the sector and the 
benefits international students bring to Australia. The strategy, for instance is committed to building bridges between Australia and the rest of the world through international education as noted in the following statement:

It offers opportunities to build enhanced bilateral and multilateral relationships, which increase cultural awareness and social engagement. In addition, diplomacy is advanced through Australian educated alumni who develop lasting connections at personal, organisational and government levels. All of this is fostering better relationships with our regional neighbours and the rest of the world. (Australian Government, 2016, p. 7).

Doing so allows the broader population to understand international students better and their contributions to Australia. Perhaps the most obvious question to raise is what impact does the strategy potentially have on institutions?

\section{The challenge of increasing numbers and diversity, and what can be done}

The strategy maps out the benefits of expanding the international education sector by providing strategies for attracting international students to Australia. However what the strategy does not do is suggest the ways in which institutions will be supported to meet increasing numbers of diverse students on their campuses. What can institutions do in this case and what are the overall implications for quality issues in general and the pursuit of quality cultures at the campus level in particular? Providing all students with both global and local perspectives

One of the challenges institutions face is supporting staff to negotiate through large and increasingly multicultural classrooms in both the real as well as virtual spaces. Work in the area of international student engagement in the classroom is readily available as resources and educators need to be pointed into these areas.

Organisations such as ISANA: International Education Association, which represents professionals in Australia and New Zealand working in international student services, advocacy and teaching and policy development in international education conducts 
yearly conferences with cutting edge research into international education and international student issues. In 2010 a group of Melbourne-based academics from the University of Melbourne and RMIT University provided a ground-breaking report on how to engage with international students in the classroom. Lead by Sophie Arkoudis, the report, called Finding common ground: Enhancing interaction between domestic and international students, provides an effective and practical guide to harnessing diversity in the classroom by promoting "winteraction between students from diverse cultural and linguistic backgrounds'"' (Arkoudis et al., p.6).

In general, universities need also to encourage and support staff in creating courses that allow for this range of international diversity to shine through. By diversity, domestic students should also be included into this conversation. Here using real world examples from the regions and students' host countries would enhance the learning experience (McLoughlin and Lee, 2009). While Australian institutions and students unquestionably provide international students with local perspectives, international students are able to repay in kind given sufficient opportunities. Much is gained within academic settings if international students can be seen as far more than merely consumers of an educational "product" but rather as drivers of a global outlook within the content of current and future courses. International students can provide local students with global perspectives both incidentally (e.g. through classroom discussions) as well as directly (e.g. through course material). With this merger of student populations and pedagogic intentions both local and international students can be prepared for future employability in the global workforce. Moreover the incorporation of both local and international examples is something I use in my own teaching to encourage more student 
interaction plus increasing both local and international students" knowledge of each other's cultural and social environments.

\section{A Case study of teaching large and diverse classes in the humanities}

Since joining the School of Media and Communication at RMIT in 2007, I have been fortunate enough to teach at various times in the School of Media and Communication exciting humanities courses to large and diverse student cohorts in different programs such as: the Asian Media and Culture (AMC) Major, the Communication Strand, the Singapore Mass Communication program and the Master of Communication program. I have, in other words, been developing, coordinating and teaching courses at the undergraduate (first to third year) and postgraduate levels, in onshore and offshore programs, and to students from all the professional programs in the Bachelor of Communication. In each program, I further encounter large and diverse student bodies with my courses enrolling between 80 to 500 students. The mode of delivery of my courses is lecture-tutorial style. While the lecture includes all enrolled students, each tutorial is made up of no less than 25 students. Approximately half of my students are international students from Asia who predominantly come from Southeast Asia (Singapore, Malaysia, Indonesia and Vietnam) and Mainland China.

Maintaining quality assurance standards for such large, culturally and nationally diverse cohorts is challenging but not impossible. Here, I develop courses which arm students with theoretical frameworks and real world examples in order to push them to critically engage with cultural artefacts while providing timely and generous feedback on assessments. The development of courses goes hand in hand with maintaining good communication with tutoring staff. The professional relationship between course coordinator and tutoring staff is vital in teaching large 
and diverse cohorts. To develop and maintain this relationship, I am in ongoing email contact with tutoring staff. I also have regular weekly meetings to discuss any issues with the course material or with students that develop in class. These weekly meetings are beneficial in providing support for tutoring staff since the majority of them are casual staff themselves engaging in postgraduate study (e.g. masters and doctoral research students). While I do not micromanage my tutors when it comes to the ways in which they run their tutorials, I provide them with weekly tutorial outlines (e.g. leading questions and learning activities for mass student participation) that assist them maintain quality standards. Allowing tutors some independence in how they run their tutorials is crucial for their own development as teachers and as future university lecturers.

As the objectives of the courses I teach are to make students aware of Asia in the AMC Major and to critically investigate Australian, particularly indigenous, cultural artefacts in the Communication Strand courses, I make frequent use of material from everyday culture and life such as visual images and soundtracks sourced from different media that include film, television and the internet. I also take students on fieldtrips and introduce them to significant members of the community in order to critically engage and contextualize the themes of the course. To make sure that the objectives of these courses are met, assessments are designed to test students on their ability to read and critically engage with both the set readings and the wider scholarship and to use the concepts that they learn and apply them to the cultural texts which they choose. Here key concepts are emphasized and students have the freedom to choose cultural artefacts and apply these concepts in their analysis. Since weekly tutorials are two hours long, part of the time is converted into workshops to help students with their work-in-progress assignments. Students sit in groups and 
discuss their work-in-progress assignments with their tutor and with their group. Generous feedback and support thus are provided by both tutor and peers. Students in other words are academically supported throughout the course.

Asia comes alive in the AMC Major with courses such as Modern Asia, Sex and Gender in Asia, and Adventures in Asian Popular Culture. Here I not only refer to media artefacts (adding to the traditional list new arrivals on the scene like social media and mobile phone technology) but also on student experiences of Asia. My AMC courses, which often see 80 to 170 students enrolled, emphasize that Asia is around us and not solely a geographical "“'alien"'” mass but rather one that is very much part of every student's daily life. The Asian international students enjoy the familiarity of Asia while discovering new things about their region through lecture and tutorial discussions. Local students realize that Asia is not north of Australia but around them in terms of their consumption of Asia through media, fashion and food. The week we look at food in Modern Asia, I bring different kinds of Asian snacks to class while the lecture uses the case study of Thai restaurants, which promise a taste of Thailand overseas. Students realize that global forces of transnationalism have affected the ways in which their diets have changed since Asian cuisine has effectively become a staple of the Australian food landscape. Meanwhile for a course in the Communication Strand called Communication and Social Relations which enrolls 500 students, for instance, the week we learn about gender in the media, students at lectures view both still and moving images of hype-rmasculinity and hyper-feminity through examples from film (for example, Hollywood and Asian cinemas) and television (Australian soaps and advertisements) while in the week we learn about the topical issue of multiculturalism in Australia, we go on a field trip during tutorials to the Immigration Museum. At the Immigration Museum students are 
tasked with choosing an artefact in order to reflect on it as the first written assignment.

Students from Communication Debates and Approaches, another Communication Strand course, which often sees no less than 300 students enrolled, choose an artefact from the Australian indigenous cultures exhibition at the Melbourne Museum and reflect about it as their first assignment in order to understand how indigenous identities are expressed and assessed through art. I also engage local Australian indigenous artists to talk to students about their work in the context of providing them the example of the indigenous voice through the creative industry. Such topics allow Media and Communication students who will be public relations practitioners, journalists, advertisers, filmmakers, television producers and designers, just to name a few, start to understand the complex issues around them. They will, after all engage with such issues in one way or another in their chosen professions. A critical engagement with such real world issues fulfils the objectives of these Communication Strand courses and thus maintains quality assurance standards. Moreover, themes involving the study of Australian indigenous cultures also allow international students an opportunity to engage with the cultural heritage of their host nation.

Maintaining quality assurance standards in courses can be made more enjoyable through interaction between teaching stuff and students. My lectures and tutorials are very interactive as students are asked to respond to the material I present to them within the framework of the concepts introduced to them. In Sex and Gender in Asia (AMC Major), for instance, students learn that gender and sexuality are complex rather than simply falling into the heterosexual normative. So I dedicate a week to discussing the transgendered kathoey of Thailand with a role playing 
activity to help students understand the experiences of the luminal sex. Since my students come from Australian and international backgrounds, I try to make my lectures more interesting. For instance, when we discussed indigenous Australian issues in Communication and Social Relations, I invited an indigenous elder to give the lecture. However, I ran the lecture like a talk show by interviewing him about growing up as an Australian indigenous person. Also, knowing that students come from a variety of programs and from a variety of countries, the artefacts I use primarily come from Australia, Asia and North America in order for the courses to be both relevant to the Australian context as well as an international one. Hence, at different stages in the courses, students are able to identify and recognize the artefacts while interrogating them critically from thematic perspectives. They also learn new material that takes the form of being introduced to new and different cultures and societies. The lack of appreciation of new and different cultures and societies, however takes a disturbing turn outside the classroom. While Australia has had decades of experience with international students, it needs to recognize that there are certain prejudices that the community holds towards them.

\section{Stereotyping international students}

When the draft strategy was first published in April 2015, I wrote an opinion piece for the online news site The Conversation (Gomes, 2015a). The comments section soon started to fill up with comments from readers - many claiming to have direct or indirect experiences with international students in the classroom either as fellow (local) students, as instructors with international students in their classes or as friends/relatives of such instructors - pointing to how expanding international education would contribute to the declining standards of the university classroom and how because of that the quality of the Australian degree would propel 
downwards since universities would have to "'dumb down"' their courses. The basic theme of the comments was that international students are not on equal footing as local students primarily because of their poor English-language skills.

In April 2015 the Australian Broadcasting Corporation (ABC) aired a Four Corners program with the title “'“Degrees of Deception"'” that turned the spotlight on international education and international students in Australia a few weeks after the release of the strategy (Besser, 2015). The program alleged that not only was international education fraught with underhanded and dishonest practice, but that international students were ill-equipped to study in Australia primarily because of poor English-language skills which led them to resorting to cheating through plagiarism. The program also claimed that international students are coming to Australia as permanent residence hunters rather as legitimate students. Interviewed for the program were former academics and casual academic staff who claimed that they were being forced by their universities to pass international students even though they were not up to standard. While Four Corners is an investigative program that specializes in exposès, it instigated a swarm of comments on its Facebook page which generally blamed international students for bringing down standards in the classroom, with a number of these comments coming from members of the public claiming to teach at universities.

\section{International students are more than just bad English speakers and permanent} resident (PR) hunters

While the Four Corners program, the resulting public comments on its Facebook page as well as the comments from my The Conversation article, emphasized international students as nothing more than hapless victims struggling with a foreign language, I see international students as having the potential to be empowered 
individuals. In my own research I see international students consistently making the effort to improve their English communication skills and provide avenues to improve their abilities in this area. As a male undergraduate respondent from China explains: "I try to talk with [Australians] but maybe because my English very poor so I can"t communicate very well. I... just think I need to improve my English skill and try to talk with them [so that I] ...feel suited [to living in]... Australia." For this student, learning English is paramount so that he is able to communicate with locals and hence feel that Australia is home for him. A number of respondents told me that they do try to improve their English-speaking skills by talking to other international students in English and by engaging in Englishlanguage entertainment and news programs which they access online. In other words, they consciously turn to Hollywood films and television shows as well as to international online news websites such as the BBC and CNN in order to improve their English-speaking skills.

International students are aware that having a good command of the English language means that they are arming themselves with the necessary skills to face the global workplace. Rather than merely being hungry for permanent residence, international students are to a significant degree international actors who consider their transient experiences in Australia as adding to their ever evolving cosmopolitanism and contributing to the internationalization of their host nation (Gomes 2015). Here I noticed that there is a new and emerging trend among international students that places global mobility at the heart of these transient migrants. In other words, international students in Australia hold aspirations for transnational mobility with ambitions to live and work in the big cities of Europe, North America and Asia with returning to the home nation a possibly in the future. 
This aspirational mobility is encouraged by their experiences in Australia in terms of their ability to form friendship networks with fellow international students and their sense of belonging to the home nation provided by rapid developments in communication and media technologies.

A possible reason why international students are stereotyped in Australia could be because of their lack of friendships with locals, particularly domestic students.

\section{Lack of local friends}

In 2013 I conducted 60 face-to-face interviews with international students in Melbourne. The findings revealed that international students strongly adhere to that identity and form a parallel multinational society made up of fellow international students that has very few "external" connections to Australian society. International students in this study note that their visa status allows them to not only identify with each other but also to provide emotional and practical support. Here they explain that only other international students will understand the challenges they face as foreign students such as loneliness and cultural shocks. They further note that only fellow international students will be able to assist them with the practical issues connected with being a foreigner such as opening bank accounts and finding grocery stores that stock the food they are used to - issues they explain that local students do not face. Unfortunately limiting social networks to only include other international students also prevents meaningful relationships being formed with locals, particularly domestic students. A female undergraduate from Singapore explains:

“I feel like students--local students— don"t really mix much with Asian[s], except for local Asians they will mix around, but not Asian-Asian." 
Clearly, the international students surveyed here are concerned by their lack of local friends, which perhaps prevents them from feeling socially connected, content and satisfied in the host nation (Hendrickson et al. 2011). Those who do count Australians as friends note that they had to actively get to know locals while at the same time developing and maintaining relationships with other international students. The participants generally state that while they would like to be friends with Australians, they feel that there are barriers to this from taking place. These include a lack of understanding of the Asian cultures the international students come from and the issues that international students encounter while in Australia (e.g. homesickness and accommodation problems) as well as language differences. The participants are resigned to the notion that the difficulties they have in speaking not only English but Australian English fluently are to blame for their lack of local friends. While researchers often point out that language is a barrier for the formation of intercultural relationships with members of the host nation (Gudykunst et al. 1991, Yamazaki et al. 1997; Kudo \& Simkin 2003), the results of my study point out that some students are taking matters in their own hands (so to speak) to remedy this situation by improving their English language skills.

Perception that Australians are White and the Inability to Connect with Asian-

\section{Australians}

While the majority of the participants have been in Australia for more than 6 months, many of them have conventional ideas about Australians as being only "White" and lack the conceptual means to differentiate that concept. The international student participants are able to see that they exist in a multicultural society made up of other international students from the homeland, region and sometimes elsewhere yet many of them read Australian society as made up almost completely of Caucasians. 
To them, an Australian friend is a white Australian friend. This notion of the Australian local population being white is not surprising since the dominant discourse in Australia is based on an Anglo-Celtic British history and culture (Hage 1998 and Statton 1999) and its local entertainment and news media are strongly dominated by white faces (Jakubowicz and Seneviratne, 1996).

At the same time, some of the participants do acknowledge that there is an Asian-Australian community, yet they also racialize this community with participants stating that their understanding of Asian-Australian is Australian born Chinese or, as they explain, "'ABCs”. Those who say that they have Asian-Australian friends state that they are new permanent residents while others explain that the ABCs only want to be friends with white Australians and not with them. Some participants provide the explanation that $A B C s$ are more Australian than Asian and hence have more in common with white Australians than they do with Asian international students. However the international students in this project also do not identify with AsianAustralian issues such as the high profile discussion in the media about the lack of diversity on Australian television. While the participants come from Asia, they find it challenging to identify with Asian-Australians and Asian-Australian issues because of the fundamental differences in direct circumstance and experience.

\section{Conclusion}

While the National Strategy for International Education 2025 is an excellent indicator of the value the Australian government places on international education and the recognition of international students in the broader contexts of cultural exchange and future professional developments for Australia, the strategy"s aspirations to expand the international education industry will pose certain challenges for institutions in terms of managing culturally diverse student bodies. In this chapter I have suggested 
that rather than looking at increasing diversity on institutional campuses because of larger numbers of international students as a difficult issue to confront, such diversity instead provides an incentive for curriculum development. However I also highlight the conundrum presented by the presence on international students in Australia. While international students have had an increasing presence in Australia since the 1950s, which accelerated from the 1980s onwards, the broader Australian community still has conventional and relatively uninformed notions about them with a possible reason being the lack of connections between international students and local students. Perhaps the continuing and persistent incorporation of both global and local examples in courses and the active use of strategies to incorporate interaction in the classroom might help reduce the disconnections between international students from Australian society while allowing local students to gain a better understanding of the cultures and societies international students come from. 


\section{References}

Arkoudis, S., X. Yu, C. Baik, H. Borland, S. Chang, I Lang, J. Lang, P. Pearce and K. Watty. 2010. Finding Common Ground: enhancing interaction between domestic and international students. Australian Learning and Teaching Council. Available online at:

http://www.cshe.unimelb.edu.au/research/projectsites/enhancing interact.html

Australian Bureau of Statistics. 2014. "Overseas Arrivals and Departures, Australia, May 2014." Available online at:

http://www.abs.gov.au/ausstats/abs@.nsf/productsbyCatalogue/568BCE24A5 E5CEC5CA257774001ABE30?OpenDocument.

Australian Department of Education and Training. 2015. "International education in Australia, 1994-2015." Department of Education and Training Media Centre. Available online at: https://internationaleducation.gov.au/research/International-StudentData/Pages/InternationalStudentData2015.aspx.

2016. Research Snapshot: International student numbers 2015. Available online at: https://internationaleducation.gov.au/research/ResearchSnapshots/Documents/Student\%20Numbers\%202015.pdf.

Australian Government .2016. National Strategy for International Education 2025. Available online at https://nsie.education.gov.au/sites/nsie/files/docs/national strategy for intern ational_education_2025.pdf.

Australian Government. 2015. Draft National Strategy for International Education: For Consultation. Available online at: https://internationaleducation.gov.au/Internationalnetwork/Australia/InternationalStrategy/Documents/Draft\%20National\%20Stra tegy\%20for\%20International\%20Education.pdf.

Australian Trade Commission. 2014. "Work while you Study." Available online at: https://www.studyinaustralia.gov.au/global/australian-education/educationcosts.

Besser, L. 2015. “Degrees of Deception. Four Corners, , April 20, 2015. Melbourne. Vic. Australian Broadcasting Corporation.

Department of Foreign Affairs and Training. 2016. "New Colombo Plan." Available online at: http://dfat.gov.au/people-to-people/new-colombo-plan/pages/newcolombo-plan.aspx.

Gomes, C. 2015a. "International student report emphasizes their value, but not the means." The Conversation.. Available online at: 
https://theconversation.com/international-student-report-emphasises-their-valuebut-not-the-means-39626\#comment 637156.

. 2015b. :Where to Next after Graduation?: International Students in Australia and their Aspirations for Transnational Mobility." Special Edition, Crossings: Journal of Migration and Culture 6, Iss. 1: 41-58.

Gudykunst, W. B., G. Gao, S. Sudweeks, S. Ting-Toomey and T. Nishida. 1991. "Themes in opposite sex, Japanese-North American relationships." In Crosscultural interpersonal communication, edited by S. Ting-Toomey and F. Korzenny. Newbury Park, CA: Sage.

Hage, G. 1998. White Nation; Fantasies of White Supremacy in a Multicultural Society. New York: Routledge.

Hendrickson, B., D. Rosen and R.K. Aune. 2011. "An Analysis of Friendship Networks, Social Connectedness, Homesickness, and Satisfaction Levels of International Students." International Journal of Intercultural Relations 35, No. 3: 281-295.

Hughes, J. 2015. "Malaysia seeks 200,000 international students by 2020." Masterstudies.com, October 15, 2015. Available online at: http://www.masterstudies.com/news/Malaysia-Seeks-200-000-InternationalStudents-by-2020-495/.

Jakubowicz, A. and K. Seneviratne. 1996. "Ethnic Conflict and the Australian Media." Making Multicultural Australia. Available online at: http://www.multiculturalaustralia.edu.au/doc/jakubowicz_3.pdf.

Kudo, K., and K. A. Simkin. 2003. "Intercultural Friendship Formation: The Case of Japanese Students at an Australian University". Journal of Intercultural Studies 24: 91-114.

McLoughlin, C. and M. J. W. Lee. 2009. "Personalized learning spaces and selfregulated learning: Global examples of effective pedagogy." Proceedings ascilite Auckland 2009. Available online at: http://citeseerx.ist.psu.edu/viewdoc/download?doi=10.1.1.412.857\&rep=rep1\& type=pdf.

Stratton, J. 1999. "Multiculturalism and the Whitening Machine, or How Australians Become White". In The Future of Australian Multiculturalism: Reflections on the twentieth anniversary of Jean Martin"s The Migrant Presence, edited by G. Hage and R. Couch. Sydney, NSW: University of Sydney: 163-188.

Student Services, The University of Melbourne. 2016. "Financial Aid." Available online at: http://services.unimelb.edu.au/finaid/planning/cost of living/summary.

Unesco. 2016. "Global flow of tertiary-level students." Unesco: Institute for Statistics, Montreal, Quebec. Available online at: 
http://www.uis.unesco.org/Education/Pages/international-student-flow-

viz.aspx.

\section{Acknowledgement}

Dr Catherine Gomes is the recipient of an Australian Research Council DECRA

Fellowship (project number DE130100551). She also receives funding from RMIT

University.

\footnotetext{
${ }^{1}$ While Australia is also host to students on exchange/study abroad, this paper does not include them under the banner of "international students". International students in this paper are full-fee paying students. In other words, their education in Australia is not subsidized by the Australian government as it is for local students. Largely international students fund their education in Australia through private means. Some students might be funded by scholarships from their home nations or by Australian programs such as the Australian Agency for International Development (AusAID) and International Postgraduate Research Scholarships (IPRS) scholarships.
} 